\title{
Application Of Discovery Learning Model To Improve Science Learning Outcomes of Electric Circuit Material In Class VI SD Muhammadiyah Sukorejo
}

\author{
Wahyu Setyoningsih \\ SD Muhammadiyah Sukorejo \\ setyoningsihwahyuwahyu@gmail.com
}

\section{Article History}

accepted 14/11/2020

approved $21 / 11 / 2020$

published 26/11/2020

\begin{abstract}
The background of this classroom action research is the low learning outcomes of science learning in class VI SD Muhammadiyah Sukorejo. Of the 25 grade VI students only 4 children completed (16\%) and 21 other children did not complete (84\%) measured by the completeness of student learning outcomes (KKM: 65.00). This classroom action research (PTK) consists of two cycles and each cycle consists of 2 meetings consisting of four stages, namely planning, implementing, observing and reflecting. The purpose of this study was to determine the amount of improvement in science learning outcomes in electrical circuit material. In this study, the action taken was learning using the discovery learning model in science learning with electrical circuit material in class VI SD Muhammadiyah Sukorejo students in semester 1 of the 2020/2021 academic year. The data obtained in this study were analyzed using comparative descriptive by comparing quantitative data from cycle I and cycle II. Based on the results of the study showed that student learning outcomes from the initial conditions an average value of 61 with completeness of $16 \%$. This condition experienced an increase in the average score of students in the first cycle, which was 69 and the percentage of completeness was $60 \%$. In the second cycle there was an increase of 82 again with a completeness percentage of $88 \%$, so that the predetermined performance indicator of $75 \%$ has been achieved. Thus it can be concluded that the application of discovery learning models in learning can improve science learning outcomes of electrical circuit material in grade VI students of SD Muhammadiyah Sukorejo semester 1 of the 2020/2021 academic year.
\end{abstract}

Keywords: learning outcomes, discovery learning model, students

\begin{abstract}
Abstrak
Latar belakang penelitian tindakan kelas ini adalah rendahnya hasil belajar IPA pada siswa kelas VI SD Muhammadiyah Sukorejo. Dari 25 siswa kelas VI hanya 4 anak yang tuntas (16\%) dan 21 anak lainnya tidak tuntas (84\%) diukur dari ketuntasan hasil belajar siswa (KKM : 65.00). Penelitian tindakan kelas (PTK) ini terdiri dari dua siklus dan tiap siklusnya terdiri dari 2 pertemuan yang terdiri dari empat tahapan yaitu perencanaan, pelaksanaan, pengamatan dan refleksi. Tujuan dalam penelitian ini adalah untuk menentukan besaran peningkatan hasil belajar IPA materi rangkaian listrik. Dalam penelitian ini tindakan yang dilakukan adalah pembelajaran menggunakan model discovery learning dalam pembelajaran IPA materi rangkaian listrik pada siswa kelas VI SD Muhammadiyah Sukorejo semester 1 tahun pelajaran 2020/2021. Data yang diperoleh pada penelitian ini dianalisis dengan menggunakan deskriptif komparatif yaitu dengan membandingkan data kuantitatif dari siklus I dan Siklus II. Berdasarkan hasil penelitian menunjukkan bahwa hasil belajar siswa dari kondisi awal nilai rata-rata sebesar 61 dengan ketuntasan sebesar $16 \%$. Kondisi tersebut mengalami peningkatan nilai rata-rata siswa pada siklus I yaitu sebesar 69 dan persentase ketuntasan sebesar $60 \%$. Pada siklus II kembali mengalami peningkatan sebesar 82 dengan persentase ketuntasan sebesar $88 \%$, sehingga indikator kinerja yang telah ditentukan sebelumnya sebesar $75 \%$ telah tercapai. Dengan demikian dapat disimpulkan bahwa penerapan model discovery learning dalam pembelajaran dapat meningkatkan hasil belajar IPA materi rangkaian listrik pada siswa kelas VI SD Muhammadiyah Sukorejo semester 1 tahun pelajaran 2020/2021.
\end{abstract}

Kata kunci: hasil belajar, model discovery learning, siswa

Social, Humanities, and Education Studies (SHEs): Conference Series p-ISSN 2620-9284 https://jurnal.uns.ac.id/shes e-ISSN 2620-9292 


\section{PENDAHULUAN}

Pendidikan adalah usaha sadar dan terencana secara etis, sistematis, intensional dan kreatif dimana siswa mengembangkan potensi diri, kecerdasan, pengendalian diri dan keterampilan untuk membuat dirinya berguna di masyarakat. Upaya peningkatan kualitas pendidikan di Indonesia tidak pernah berhenti, berbagai cara telah dilakukan oleh pemerintah agar kualitas pendidikan bisa lebih baik selain mengembangkan kurikulum pendidikan yang sudah ada, peningkatan kompetensi guru juga salah satu usaha pemerintah agar guru di Indonesia bisa lebih profesional sehingga dengan peningkatan kompetensi tujuan pendidikan akan dapat tercapai.

Kurikulum 2013 merupakan salah satu perubahan paradigma pembelajaran dari pembelajaran yang bersifat konvensional menjadi yang mengaktifkan siswa dan melatih kemampuan berpikir kreatif siswa. Kurikulum 2013 adalah kurikulum yang berbasis kompetensi, di dalamnya dirumuskan secara terpadu mencakup kompetensi sikap, pengetahuan, dan keterampilan yang harus dimiliki siswa. Oleh sebab itu, berpikir kreatif menjadi salah satu kemampuan yang dikembangkan dalam Kurikulum 2013, sehingga berpikir kreatif sangat berpengaruh terhadap hasil belajar di mana hasil belajar biasanya dipengaruhi pemahaman siswa terhadap suatu konsep pembelajaran serta kemampuan siswa untuk memecahkan suatu permasalahan dalam proses pembelajaran.

Dari hasil belajar ulangan harian IPA kelas VI SD Muhammadiyah Sukorejo menunjukkan bahwa rata-rata nilai ulangan harian belum optimal, hal tersebut dapat dilihat dari rata-rata nilai IPA hanya 61 , dengan ketuntasan belajar mencapai $16 \%$ yang nilainya diatas KKM 65. Kurang optimalnya hasil belajar tersebut disebabkan perhatian siswa saat pembelajaran kurang karena model pembelajaran yang digunakan guru kurang menarik.

Terkait belum optimalnya hasil belajar IPA pada siswa kelas VI SD Muhammadiyah Sukorejo maka peneliti berupaya untuk menerapkan model discovery learning berbantuan media visual dalam pembelajaran. Berdasarkan kondisi tersebut maka penulis tergerak untuk melakukan penelitian tindakan kelas dengan menelaah "Penerapan Model Discovery Learning Dapat Meningkatkan Hasil Belajar IPA Materi Rangkaian Listrik Pada Siswa Kelas VI SD Muhammadiyah Sukorejo Semester 1 tahun pelajaran 2020/2021.

Belajar memiliki tiga tujuan, yaitu (1) mempelajari keterampilan dan pengetahuan tentang materi -materi pelajaran spesifik; (2) mengembangkan kemampuan konseptual umum, sehingga mampu belajar menerapkan konsep yang sama atau berkaitan dengan bidang-bidang yang lain yang berberda;(3) mengembangkan kemampuan dan sikap pribadi yang secara mudah dapat digunakan dalam segala tindakan. (Hidayatullah, 2009). Dari pendapat di atas dapat disimpulkan bahwa belajar bertujuan untuk pengembangan keterampilan dan pengetahuan yang bersifat spesifik dan dapat digunakan dalam segala tindakan. Salah satu bukti bahwa seseorang telah melakukan proses belajar adalah terjadi proses perubahan pada tingkat pengetahuan, keterampilan atau sikapnya

Hasil belajar menunjukkan kepada prestasi belajar, sedangkan prestasi belajar itu merupakan indikator adanya derajat perubahan tingkah laku siswa. (Hamalik, 2001). Dari pendapat di atas dapat disimpulkan bahwa hasil belajar adalah prestasi belajar yang diperoleh siswa dari proses pembelajaran yang ditunjukaan dengan indikator perubahan baik pengetahuan, kemampuan dan keterampilan selama proses pembelajaran yang menunjukan derajat perubahan yang lebih baik.

Discovery learning adalah proses pembelajaran yang penyampaian materinya tidak utuh, karena model discovery learning menuntut siswa terlibat aktif dalam proses pembelajaran dan menemukan sendiri suatu konsep pembelajaran. (Maharani \& Hardini, 2017). Dari pendapat diatas dapat disimpulkan bahwa discovery learning adalah pembelajaran yang menuntut siswa untuk aktif dalam proses pembelajaran dan menemukan sendiri suatu konsep pembelajaran.

Langkah-langkah pengaplikasian model discovery learning yaitu (1) menentukan tujuan pembelajaran; (2) melakukan identifikasi karakteristik siswa.; (3) menentukan materi pelajaran; (4) menentukan topik-topik yang harus dipelajari siswa. secara induktif; (5) mengembangkan bahan-bahan dengan memberikan contoh, ilustrasi, tugas, dan sebagainya 
untuk dipelajari siswa; (6) mengatur topik-topik pelajaran berawal dari yang sederhana ke yang kompleks, dari yang konkret ke abstrak, dan dari tahap enaktif, ikonik sampai ke tahap simbolik; serta (7) melakukan penilaian proses dan hasil belajar siswa. (Darmadi, 2017)

Dari pendapat di atas dapat disimpulkan bahwa langkah-langkah penerapan discovery learning yaitu dengan menentukan tujuan pembelajaran, mengidentifikasi karakteristik siswa, menentukan materi; menentukan topik-topik yang harus dipelajari siswa secara induktif,mengembangkan bahan-bahan dengan memberikan contoh, ilustrasi, tugas, dan sebagainya untuk dipelajari siswa, mengatur topik-topik pelajaran berawal dari yang sederhana ke yang kompleks, dan melakukan penilaian proses dan hasil belajar siswa. Penelitian tindakan kelas ini bertujuan: Untuk menentukan besaran peningkatan hasil belajar IPA materi rangkaian listrik menggunakan model discovery learning pada siswa kelas VI SD Muhammadiyah Sukorejo semester 1 tahun pelajaran 2020/2021.

\section{METODE}

Penelitian tindakan kelas ini dilakukan pada siswa kelas VI SD Muhammadiyah Sukorejo Kendal. Pemilihan kelas VI dikarenakan peneliti mengajar di kelas tersebut sehingga memudahkan teknis pengumpulan data dan peneliti juga terlibat langsung dalam proses pembelajaran di kelas khususnya dalam mencermati berbagai permasalahan yang muncul dalam pembelajaran. Penelitian ini dilaksanakan pada semester I tahun pelajaran 2020/2021. Subjek penelitian dalam penelitian tindakan kelas ini adalah semua siswa kelas VI SD Muhammadiyah Sukorejo semester 1 tahun pelajaran 2020/2021, yang berjumlah 25 anak yang terdiri dari 11 siswa laki-laki dan 14 siswa perempuan. Teknik pengumpulan data dalam penelitian ini meliputi teknik tes dan non tes. Teknis tes berupa tes tertulis sedangkan teknik non tes berupa observasi. Hasil belajar IPA diukur dengan teknik tes berupa pemberian soal secara tertulis sejumlah 10 soal isian singkat, selama siklus penelitian berlangsung. Aktivitas belajar diukur dengan teknik nontes yakni menggunakan lembar observasi. Analisis data dilakukan dengan cara merefleksi hasil observasi dan evaluasi terhadap proses pembelajaran yang dilaksanakan oleh guru dan siswa di lapangan dan diolah menjadi kalimat yang bermakna dan dianalisis. Data yang diperoleh pada penelitian ini dianalisis dengan menggunakan deskriptif komparatif yaitu dengan membandingkan data kuantitatif dari siklus I,siklus II

\section{HASIL DAN PEMBAHASAN}

Dalam tahap perencanaan, peneliti merencanakan kegiatan pembelajaran dan juga menyiapkan fasilitas pendukung untuk melaksanakan kegiatan pembelajaran tersebut. Pembelajaran siklus I pertemuan ke-1 dilaksanakan pada 2 dan 3 November 2020 dengan alokasi waktu 2 × 35 menit meliputi. Secara rinci kegiatan pembelajaran adalah sebagai berikut:

Menyusun rencana pelaksanaan pembelajaran (RPP). Kompetensi Dasar: 3.2 Menggali isi teks penjelasan(eksplanasi) ilmiah yang; 3.4 Mengidentifikasi komponenkomponen listrik dan fungsinya dalam rangkaian listrik sederhana. Menyiapkan media yang akan digunakan dalam pelaksanaan proses pembelajaran yaitu laptop dan lembar penilaian. Menyusun instrumen penelitian.

Guru melakukan pembukaan dengan salam dan dilanjutkan dengan membaca doa dipandu melalui grup WA. (Orientasi). Guru mengecek kehadiran siswa melalui WA.Guru mengajak siswa untuk menerapkan protokol kesehatan dalam kegiatan sehari-hari di masa pandemi covid sekarang ini. (Apersepsi).Guru menjelaskan tujuan tentang materi yang akan di pelajari hari ini. Guru memberikan gambaran tentang manfaat mempelajari pelajaran yang akan dipelajari dalam kehidupan sehari-hari. (Motivasi).

Siswa membaca cerita tentang "Listrik, Pengubah Dunia" yang dikirim melalui WAG .(Literasi, TPACK ).Siswa menemukan informasi penting dan menuliskan jawaban pada 
diagram yang tersedia dan menyesuaikan dengan urutan paragrafnya.(HOTS, Creativity).Siswa memeriksa ulang jawaban mereka dengan menjawab pertanyaan-pertayaan yang terdapat di buku untuk memastikan bahwa jawaban t)ersebut benar dan sesuai dengan isi bacaan.( Creativity).Siswa mendiskusikan jawaban bersama teman (Comunication).Siswa menyampaikan hasil temuan kepada guru melalui video yang dikirim ke WAG. (TPACK, HOTS) (Critical Thinking and Problem Formulation).Guru memberikan penguatan. Ayo Mengamati (Melalui bimbingan guru di aplikasi ZOOM: (TPACK)

Siswa melakukan pengamatan materi tentang konsep rangkaian listrik seri melalui tampilan powerpoint.(Discovery Learning 1 Stimulation).Siswa mengidentifikasi benda-benda yang memiliki rangkaian listrik seri.(Discovery Learning 2 Problem Statemen).Siswa mencari rangkaian listrik seri yang ada dirumah ( Creativity ).(Discovery Learning 3 Data Collection).Siswa mengamati kompoen rangkaian lampu seri tersebut. ( Creativity)(HOTS) (discovery learning 3 Data Collection).Guru memberikan bimbingan dengan menanyakan sejauh mana hasil yang diamati(discovery learning 4 Data Procesing).Siswa dapat menentukan komponen rangkaian listrik seriyang ada di rumah tersebut(discovery learning 5).Siswa menuliskan hasil pengamatan tentang rangkaian listrik seri yang ada di dalam rumah dan dikirim melalui WAG ( Creativity)(discovery learning 6 Generalization).Guru memeriksa tulisan dan gambar hasil pengamatan siswa dan memastikan ketepatan tulisan mereka, yang dikirim melalui WAG.(TPACK).

Siswa melakukan perenungan dengan menjawab pertanyaan yang terdapat di buku paket yang sudah dibagikan (reflective). Guru dan siswa menyimpulkan materi yang sudah dipelajari pada hari ini.(decision making).Siswa menceritakan kegiatan mereka hari ini pada orang tua di rumah. Siswa membuat resume (CREATIVITY) dengan bimbingan guru tentang point -point penting yang muncul dalam kegiatan pembelajaran tentang materi yang baru dilakukan. Guru : Memeriksa pekerjaan siswa yang sudah dikirim.

Berdasarkan hasil IPKG 1 tentang penyusunan (RPP) siklus I diperoleh skor sebesar 71,76 dalam kategori cukup dan IPKG 2 tentang pelaksanaan pembelajaran diperoleh data rata-rata skor 76,55 termasuk kategori baik. Hasil evaluasi akhir pembelajaran juga mengalami peningkatan dibandingkan dengan kondisi awal pada pembelajaran IPA rangkaian listrik seri. Selengkapnya dapat dilihat pada tabel berikut:

Tabel 1. Distribusi Frekuensi Hasil Belajar Rangkaian Listrik Seri Siklus I

\begin{tabular}{|c|ccc|c|c|c|}
\hline No & \multicolumn{3}{|c|}{ Interval } & Frekuensi & Persentase & Kategori \\
\hline 1 & 88 & - & 100 & 1 & $4 \%$ & Sangat baik \\
\hline 2 & 76 & - & 88 & 6 & $24 \%$ & Baik \\
\hline 3 & 65 & - & 76 & 8 & $32 \%$ & Cukup \\
\hline 4 & \multicolumn{3}{|c|}{$<65$} & 10 & $40 \%$ & Perlu bimbingan \\
\hline \multicolumn{3}{|c|}{ Jumlah } & 25 & $100 \%$ & \multicolumn{4}{c|}{$69 \%$} \\
\hline \multicolumn{3}{|c|}{ Rata-rata } & \multicolumn{4}{c}{$60 \%$} \\
\hline \multicolumn{3}{|c|}{ Ketuntasan } &
\end{tabular}

Dari tabel di atas diketahui bahwa 1 anak (4\%) memperoleh hasil belajar rangkaian listrik seri dalam kategori sangat baik, 6 anak (24\%) kategori baik, 8 anak (32\%) kategori cukup, dan 10 anak (40\%) kategori perlu bimbingan. Bila dilihat dari rata-rata hasil belajar sebesar 69 kategori cukup dengan ketuntasan mencapai $60 \%$. Selengkapnya dapat dilihat dalam grafik batang berikut ini: 
SHEs: Conference Series 3 (3) (2020) $739-745$

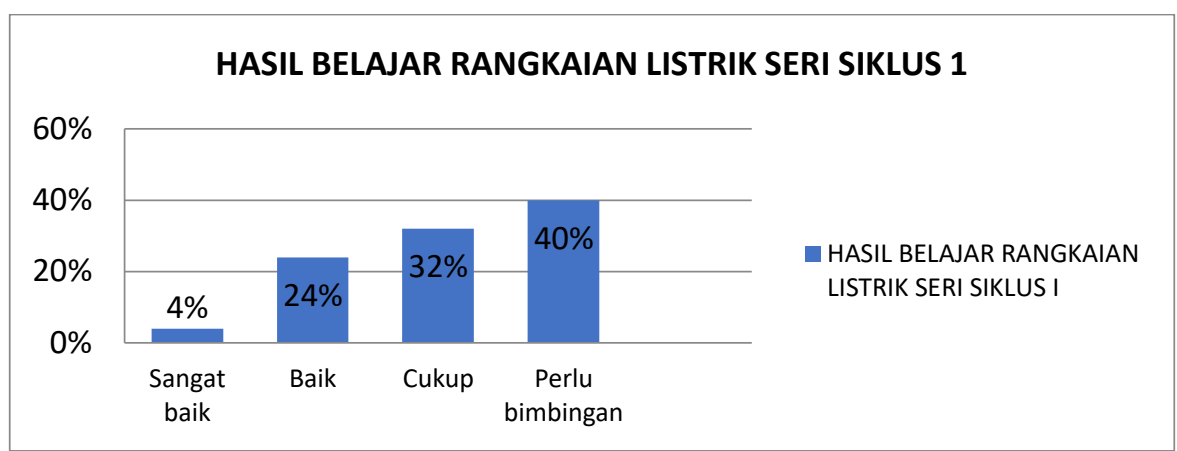

Gambar 1. Hasil Belajar Siklus 1

Berdasarkan hasil observasi peneliti dan kolabolator melakukan refleksi sebagai berikut: Rata-rata hasil belajar siswa mengalami peningkatan, pada kondisi awal hanya sebesar 61 naik menjadi 69 pada siklus I; Ketuntasan hasil belajar IPA mengalami peningkatan yaitu pada kondisi awal sebesar $16 \%$ naik menjadi $60 \%$ pada siklus I. Dalam tahap perencanaan, peneliti merencanakan kegiatan pembelajaran dan juga menyiapkan fasilitas pendukung untuk melaksanakan kegiatan pembelajaran tersebut. Pembelajaran siklus I pertemuan ke-1 dilaksanakan pada 9 dan 10 November 2020 dengan alokasi waktu 2 x 35 menit meliputi. Secara rinci kegiatan pembelajaran adalah sebagai berikut:

Menyusun rencana pelaksanaan pembelajaran (RPP). Kompetensi Dasar: 3.2 Menggali isi teks penjelasan(eksplanasi) ilmiah yang; 3.4 Mengidentifikasi komponenkomponen listrik dan fungsinya dalam rangkaian listrik sederhana. Menyiapkan media yang akan digunakan dalam pelaksanaan proses pembelajaran yaitu laptop dan lembar penilaian. Menyusun instrumen penelitian.

Guru melakukan pembukaan dengan salam dan dilanjutkan dengan membaca doa dipandu melalui grup WA. (Orientasi). Guru mengecek kehadiran siswa melalui WA. Guru mengajak siswa untuk menerapkan protokol kesehatan dalam kegiatan sehari-hari di masa pandemik covid sekarang ini. (Apersepsi). Guru menjelaskan tujuan tentang materi yang akan di pelajari hari ini. Guru memberikan gambaran tentang manfaat mempelajari pelajaran yang akan dipelajari dalam kehidupan sehari-hari. (Motivasi)

Siswa membaca cerita dari teks eksplanasi yang dikirim melalui WAG.Literasi, TPACK. Siswa menemukan informasi penting dan menuliskan jawaban pada diagram yang tersedia dan menyesuaikan dengan urutan paragrafnya.(HOTS, Creativity). Siswa memeriksa ulang jawaban mereka dengan menjawab pertanyaan-pertayaan yang terdapat di buku untuk memastikan bahwa jawaban tersebut benar dan sesuai dengan isi bacaan.( Creativity). Siswa mendiskusikan jawaban bersama teman (Comunication). Siswa menyampaikan hasil temuan kepada guru melalui video yang dikirim ke WAG. (TPACK, HOTS)(Critical Thinking and Problem Formulation). Guru memberikan penguatan. Ayo Mengamati (Melalui bimbingan guru di aplikasi ZOOM: (TPACK).

Siswa melakukan pengamatan materi tentang konsep rangkaian listrik paralel melalui tampilan powerpoint.(Discovery Learning 1 Stimulation). Siswa mengidentifikasi benda-benda yang memiliki rangkaian listrik paralel.(Discovery Learning 2 Problem Statemen). Siswa mencari bahan dan alat yang diperlukan ,kemudian berusaha menyusun rangkaian listrik paralel.( Creativity )(Discovery Learning 3 Data Collection). Guru memberikan bimbingan kepada siswa saat menyusun rangkaian listrik parallel (discovery learning 4 Data Procesing). Siswa membuat model rangkaian lampu paralel yang siswa ketahui.(Creativity and Innovation) (discovery learning 5 Verification). Siswa dapat menyimpulkan hasil pengamatan tentang rangkaian listrik parallel yang ditemukan. (Creativity )(discovery learning 6 Generalization)

Siswa melakukan perenungan dengan menjawab pertanyaan yang terdapat di buku paket yang sudah dibagikan (reflective). Guru dan siswa menyimpulkan materi yang sudah dipelajari pada hari ini.(decision making).Siswa menceritakan kegiatan mereka hari ini pada orang tua di rumah. Siswa membuat resume (CREATIVITY) dengan bimbingan guru tentang 
point -point penting yang muncul dalam kegiatan pembelajaran tentang materi yang baru dilakukan. Guru : Memeriksa pekerjaan siswa yang sudah dikirim.

Berdasarkan hasil IPKG 1 tentang penyusunan Rencana Pelaksanaan Pembelajaran (RPP) siklus 2 diperoleh skor sebesar 76,55 dalam kategori baik dan IPKG 2 tentang pelaksanaan pembelajaran diperoleh data rata-rata skor 90,34 termasuk kategori baik. Hasil evaluasi akhir pembelajaran juga mengalami peningkatan dibandingkan dengan siklus 1 pada pembelajaran IPA. Selengkapnya dapat dilihat pada tabel berikut:

Tabel 2. Distribusi Frekuensi Hasil Belajar Rangkaian Listrik Paralel Siklus II

\begin{tabular}{|c|ccc|c|c|c|}
\hline No & \multicolumn{3}{|c|}{ Interval } & Frekuensi & Persentase & Kategori \\
\hline 1 & 88 & - & 100 & 13 & $52 \%$ & Sangat baik \\
\hline 2 & 76 & - & 88 & 5 & $20 \%$ & Baik \\
\hline 3 & 65 & - & 76 & 4 & $16 \%$ & Cukup \\
\hline 4 & \multicolumn{3}{|c|}{ Jumlah } & 3 & $12 \%$ & Perlu bimbingan \\
\hline \multicolumn{3}{|c|}{ Rata-rata } & 25 & $100 \%$ & \\
\hline \multicolumn{3}{|c|}{ Ketuntasan } & \multicolumn{4}{c|}{$82 \%$} \\
\hline
\end{tabular}

Dari tabel di atas diketahui bahwa 13 anak (22\%) memperoleh hasil belajar rangkaian listrik paralel dalam kategori sangat baik, 5 anak (20\%) kategori baik, 4 anak (16\%) kategori cukup, dan 3 anak (12\%) kategori perlu bimbingan. Bila dilihat dari rata-rata hasil belajar sebesar 82 kategori cukup dengan ketuntasan mencapai $88 \%$. Selengkapnya dapat dilihat dalam grafik batang berikut ini:

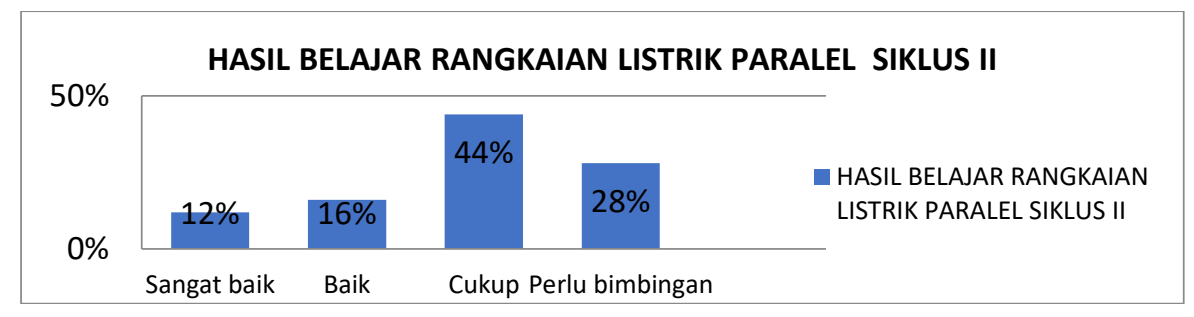

Gambar 2. Hasil Belajar Siklus 2

Rata-rata hasil belajar siswa IPA mengalami peningkatan, pada siklus I hanya sebesar 69 naik menjadi 82 pada siklus II. Ketuntasan hasil belajar IPA mengalami peningkatan yaitu pada siklus I sebesar $60 \%$ naik menjadi $88 \%$ pada siklus II. Karena prosentase ketuntasan hasil belajar sudah mencapai dari indikator kinerja sebesar $75 \%$ maka penelitian dicukupkan sampai disini.

\section{SIMPULAN}

Penerapan model discovery learning dalam pembelajaran dapat meningkatkan hasil belajar IPA materi rangkaian listrik pada siswa kelas VI SD Muhammadiyah Sukorejo semester 1 tahun pelajaran 2020/2021. Hal ini dibuktikan dari hasil belajar pada kondisi awal hanya ketuntasan belajar hanya mencapai $16 \%$ dengan rata-rata 61 mengalami peningkatan pada siklus I dengan ketuntasan belajar $60 \%$ dengan nilai rata-rata 69 dan meningkat lagi pada siklus II dengan ketuntasan belajar mencapai $88 \%$ dengan nilai rata-rata 82 . Pembelajaran dengan menggunakan model discovery learning dapat dijadikan referensi model pembelajaran yang kreatif dan inofativ bagi guru dan bisa diterapkan pada mata pelajaran yang lain.

\section{DAFTAR PUSTAKA}

Darmadi. 2017. Pengembangan model dan metode pembelajaran dalam dinamika belajar siswa. Yogyakarta: CV Budi Utama. 
SHEs: Conference Series 3 (3) (2020) $739-745$

Hamalik, Oemar. 2001. Psikilogi Belajar dan Mengajar. Bandung : Sinar Baru Algensindo.

Hidayatullah, M.F. 2009. Guru Sejati Membangun insane berkarakter kuat dancerdas.Surakarta: Yuma Pustaka.

Maharani, Y. B., \& Hardini, I. T. A. 2017. Penerapan model pembelajaran discovery learning berbantuan benda konkret untuk meningkatkan hasil belajar IPA. Jurnal Mitra Pendidikan, 1 (5), 249-561. 